\title{
Comparison of the solophenyl-red polarization method and the immunohistochemical analysis for Collagen Type III
}

\author{
P. Betz ${ }^{1}$, A. Nerlich ${ }^{2}$, J.Wilske ${ }^{1}$, I. Wiest ${ }^{2}$, R.Penning ${ }^{1}$, and W. Eisenmenger ${ }^{1}$ \\ Departments of ${ }^{1}$ Legal Medicine and ${ }^{2}$ Pathology, University of Munich, Frauenlobstrasse 7a, W-8000 München 2 , \\ Federal Republic of Germany
}

Received October 29, 1991 / Received in revised form January 31, 1992

\begin{abstract}
Summary. In the present study, we have compared the staining pattern of the Solophenyl-Red 3 BL-method for the visualization of collagen type III with the immunohistochemical staining in serial sections from 7 skin wounds (wound age 3 days up to 4 weeks) to elucidate the specifity of the histochemical staining method. Large amounts of collagen type III were clearly detectable in the investigated wounds using the immunohistochemical technique. In the sections stained with Solophenyl-Red, however, only 3 out of 7 skin lesions showed a significant positive red staining at the wound margin or in the granulation tissue, while the adjacent normal connective tissue revealed a typical intensive staining. Using polarization microscopy no characteristic bright green fibrils, as reported for collagen type III, could be seen in the wound areas without positive Solophenyl-Red staining. Since the localization of collagen type III detected by immunohistochemistry and the presumed distribution of this collagen type by the Solophenyl-Red method was not identical, the histochemical polarization method has to be regarded as non-specific for visualization of this collagen type.
\end{abstract}

Key words: Immunohistochemistry - Histochemistry Collagen Type III - Solophenyl-Red 3 BL

Zusammenfassung. Zur Überprüfung der Spezifität der histochemischen Darstellung von Kollagen Typ III wurden Serienschnitte von 7 Hautwunden mit einem Wundalter zwischen 3 Tagen und 4 Wochen untersucht. Korrespondierende Präparate wurden nach der SolophenylRot 3 BL-Methode und immunhistochemisch gefärbt, die Schnitte wurden licht- bzw. polarisationsmikroskopisch ausgewertet. Immunhistochemisch konnte in allen untersuchten Hautwunden Kollagen Typ III nachgewiesen werden. Nur 3 von 7 Solophenyl-Rot-gefärbten Hautwunden zeigten eine signifikante Rotfärbung im Bereich der Läsion bei kräftiger Anfärbung des umgebenden Bin-

This study was supported by a grant from the "Deutsche Forschungsgemeinschaft" (Ei 209/3-1) and by a grant from the "Friedrich-Baur-Stiftung", University of Munich, FRG

Correspondence to: P. Betz degewebes. Im polarisierten Licht konnten im Wundgebiet keine grün aufleuchtenden Fasern, die als charakteristisch für Kollagen Typ III aufgefaßt werden, beobachtet werden. Da keine Übereinstimmung zwischen immunhistochemisch darstellbarem Kollagen Typ III und den unter polarisiertem Licht grünweiß aufleuchtenden Fasern in den Solophenyl-Rot-gefärbten Präparaten nachzuweisen war, muß eine Spezifität dieser histochemischen Färbemethode für Kollagen Typ III verneint werden.

Schlüsselwörter: Immunhistochemie - Histochemie Kollagen Typ III - Solophenyl-Rot 3 BL

\section{Introduction}

During reparative processes, especially wound healing, various collagen types play important roles in tissue rearrangement. The time-dependent appearance of different collagen types can be demonstrated by immunohistochemistry and the specific detection of collagen types I, III and IV is useful for the estimation of wound age [2].

Recently, in addition to the specific immunohistochemical method, a histochemical polarization technique has been described which seemed to allow differentiation between collagen types I and III in paraffin sections $[4,5,13]$. In our present study we compared the Solophenyl-Red 3 BL method described by Ogbuihi et al. [13] with the immunohistochemical localization of collagen type III in formalin fixed and paraffin embedded tissue to analyze the specificity of this histochemical polarization technique for visualizing collagen subtypes.

\section{Material and methods}

Tissue preparation. Surgical wound specimens from 7 males and females (aged 43-92 years) with a wound age of 3 days up to 4 weeks were investigated. All patients died from car accidents. Undamaged skin was obtained from the same body region (arm or leg) and used as a control. In no case had substances (c.g. glucocorticoids) influencing the metabolism or distribution of collagen 


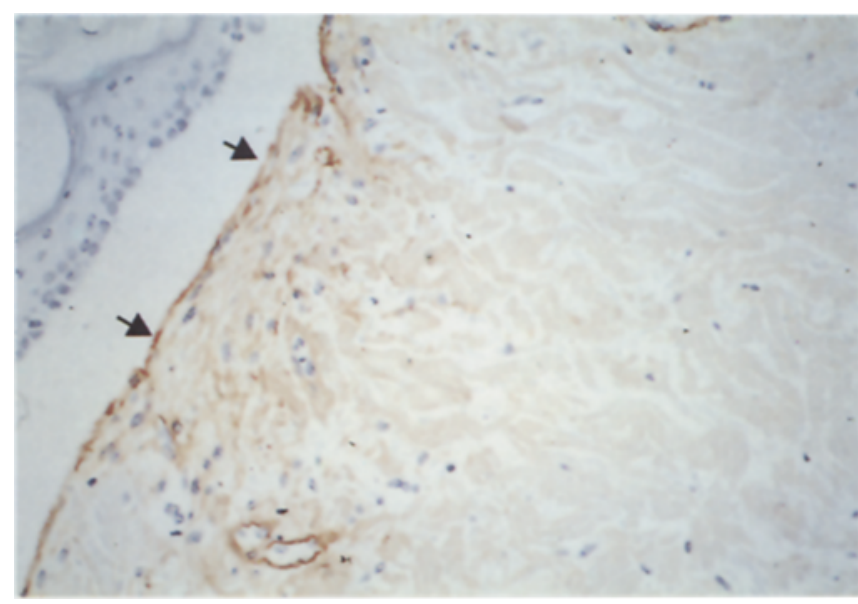

Fig. 1. 11-day-old skin wound: distinct immunohistochemical staining for collagen type III at the wound margin (arrows), (ABCmethod, paraffin, section magnification $200 \times$ )

types been administered to our knowledge. The postmortem interval did not exceed 2 days.

The specimens were fixed in $4 \%$ PBS formaldehyde solution and routinely embedded in paraffin. From this material $2-3 \mu \mathrm{m}$ thick serial sections were prepared and stained according to the Solophenyl-Red 3 BL method described by Ogbuihi et al. [13] as well as by immunohistochemistry.

Preparation of the antibody. The collagen III antibody had been prepared as previously described by Timpl et al. [16]. Briefly, human fetal skin was used for the extraction of collagen type III by enzymatic treatment with pepsin and several purification steps by repeated salt precipitation as described [16]. Antibodies against collagen type III were raised in rabbits by immunization with the prepared antigen. The rabbit antiserum was then purified by crossabsorption which collagen types I, II and V on sepharose gel columns. The specificity of the resulting antibody was demonstrated by enzyme-linked immuno-sorbent assay (ELISA) showing exclusively type-specific reaction of the prepared antibody with collagen III [11].

Immunohistochemistry. For immunohistochemistry, deparaffinized sections were pretreated enzymatically (pronase) as described [12]. Following application of the specific primary antibody, an avidinbiotin labelled secondary antibody (Vector, Burlingame, USA) was applied using the ABC-technique [3]. 3-Amino-9-ethyl carbazole (Sigma chemicals, Deisenhofen, FRG) was used as chromogene. In the stained sections the distribution of collagen type III was investigated by light microscopy. The sections treated with Solophenyl-Red $3 \mathrm{BL}$ were additionally evaluated by polarization microscopy as described [13].

\section{Results}

\section{Immunohistochemistry}

In normal skin collagen type III is found in the dermal connective tissue and shows an especially strong positive reaction in the papillary layer, in the walls of blood vessels, around the skin appendages and surrounding individual fat cells. In the skin wounds we detected a loose, but distinctly reacting network of collagen type III in lesions of early wound age ( 3 days) with increasing intensity at the margin dependent on the wound age (Fig.1).

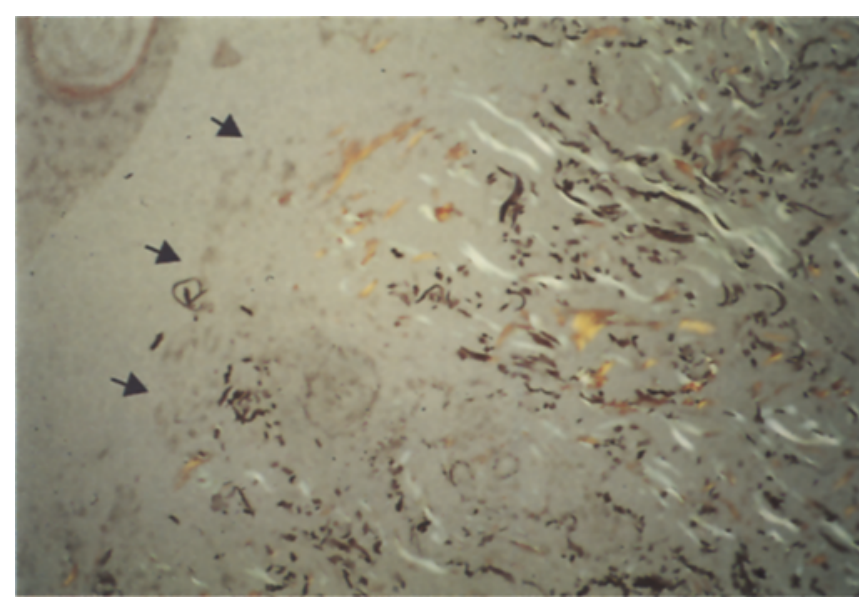

Fig. 2. Same specimen as Fig. 1: green-white and orange fibers in the connective tissue adjacent to the wound margin (arrows); no identical localization between green bright fibers and collagen type III detected by immunohistochemistry (see Fig. 1) (SolophenylRed $3 \mathrm{BL}$, polarization microscopy, paraffin, section magnification $200 \times$ )

The older wounds investigated (wound age 28 days and 31 days) were characterized by extensive fibro-proliferative processes and showed a strong diffuse positive staining with network-like structures in the granulation tissue.

\section{Solophenyl-Red 3 BL staining}

The corium of normal skin showed an extensive positive red staining, which was focally reduced in the papillary layer. Elastic fibers showed a dark brown colour between the red stained fibers of the corium as well as in the walls of arterial vessels. Using polarization microscopy the Solophenyl-Red positive fibers of the corium showed a mixture of red-orange and green-white fibrils. In the papillary layer, in particular, the green polarization was somewhat pronounced. However, in the walls of arterial vessels and around the skin appendages the expected green polarization was not detectable and there was no significant staining around fat cells.

Only in 3 out of 7 specimens could a positive Solophenyl-Red staining be observed at the wound margin, although in serial sections those areas negative for Solophenyl-Red mostly showed a strong immunohistochemical reaction for collagen type III. In 2 cases there was an intense positive immunohistochemical reaction, but only a very sparse red staining after treatment with Solophenyl-Red (Fig. 2). One specimen showed no red staining at all at the margin, but a strongly positive SolophenylRed reaction in the adjacent corium. In these cases polarization microscopy revealed only a very faint or even complete lack of green-white fibers.

\section{Discussion}

The specific detection of various collagen types is of great importance for a reliable forensic estimation of the wound age. Thus, Eisenmenger and co-workers had shown a 
time-dependent distribution of collagen types I, III and IV in human skin wounds [2].

There is no doubt, that various collagen types can be specifically localized by immunohistochemical methods using specific antibodies without any cross-reaction to other matrix proteins. Previously, histochemical techniques have been described which were thought to enable a differentiation between collagen types I and III following the staining of paraffin sections with Picro-Sirius-Red Supra $[4,5]$ or with Solophenyl-Red 3 BL [13]. The effect of these histochemical reactions was based on the assumption that collagen type I builds "thick" bundles which fluoresce red-orange in polarization microscopy, while collagen type III represents reticular fibers flourescing green under polarized light.

The specificity of this reaction was based on the similar localization of "green" and "red-orange" fibers in areas where high contents in collagen I and III had been estimated biochemically [6]. However, no direct comparison with immunohistochemical methods has yet been performed.

Various previous studies have shown that "thin" reticular fibers contain not only collagen type III, but also collagen type I $[9,10,17]$ and fibronectin $[1,15]$. Furthermore collagen type IV was detected in typical reticular fibers of lymph nodes [7]. It would seem, that the thin reticular fibers which fluoresce green under polarized light additionally contain some as yet unidentified components, perhaps other collagen subtypes. Therefore the identification of green fibers in polarization microscopy following Solophenyl-Red staining as collagen type III fibers seems to be very questionable.

Similar doubts on the specifity of the reaction have been raised by Piérard [14]. He found a varying distribution of bright green fibers under polarized light in serial sections of the same specimen and also described a change in colour depending on the position of the section under the microscope. Furthermore, the specifity of the PicroSirius-Red method for typing different collagen subtypes has been questioned by the original describers of this method [8].

In all skin lesions investigated in our study the detection of collagen type III at the wound margin or in the granulation tissue was possible by immunohistochemistry. The Solophenyl-Red treated sections, however, showed a rather varied reaction ranging from no staining in the wound area eventhough the serial sections showed a strong positive signal by immunohistochemistry to positive reaction in areas where no collagen III could be localized by immunohistochemistry. A co-distribution between the histochemical and the immunohistochemical staining pattern could not be found.

Our investigations substantiate the notion that the histochemical polarization method using Solophenyl-Red $3 \mathrm{BL}$ is not specific for the visualization for collagen type III and thus is not applicable for the differentiation of collagen types I and III. The histochemical techniques appear to be useful for the determination of the fiber diameter $[8,14]$ based on the specific physicochemical characteristics of birefringency of "thick" and "thin" collagen fibers. A specific detection of various collagen subtypes, however, is not possible. Therefore these methods could not be used for the analysis of time-dependent tissue changes, especially not for a forensic estimation of wound age.

Acknowledgements. We greatfully acknowledge the help of Dr. R. Brenner, Department of Pediatrics, University of Ulm, FRG, previously Max-Planck-Institut für Biochemie, Martinsried, FRG, in preparing the collagen type III antibodies.

\section{References}

1. D’Ardenne AJ, Burns J, Sykes BC, Kirkpatrick P (1983) Comparative distribution of fibronectin and type III collagen in normal human tissues. J Pathol 141:55-69

2. Eisenmenger W, Nerlich A, Glück G (1988) Die Bedeutung des Kollagens bei der Wundaltersbestimmung. Z Rechtsmed 100:79-100

3. Hsu SM, Raine L, Fanger H (1981) A comparative study of the peroxidase-antiperoxidase method and an avidin-biotin complex method for studying polypeptide hormones with radioimmunoassay antibodies. Am J Clin Pathol 75:734-738

4. Junqueira LCU, Cossermelli WS, Brentani RR (1978) Differential staining of collagens type I, II, and III by Sirius Red and polarization microscopy. Arch Histol Jap 41 : 267-274

5. Junqueira LCU, Bignolas G, Brentani RR (1979) Picrosirius staining plus polarization microscopy, a specific method for collagen detection in tissue sections. Histochem $\mathbf{J} 11: 447-455$

6. Junqueira LCU, Montes GS, Martins JEC, Joazeiro PP (1983) Dermal collagen distribution. Histochemistry 79:397-403

7. Kramer RH, Rosen SD, McDonald KA (1988) Basement-membrane components associated with the extracellular matrix of the lymph node. Cell Tissue Res 252:367-375

8. Line SRP, Torloni H, Junqueira LCU (1989) Diversity of collagen expression in the pleomorphic adenoma of the parotid gland. Virchows Arch [A] 414:477-483

9. Macarak EJ, Howard PS, Lally ET (1986) Production and characterization of a monoclonal antibody to human type III collagen. J Histochem Cytochem 34:1003-1011

10. Mark K von der (1981) Localization of collagen types in tissues. Int Rev Connect Tissue Res 9:265-324

11. Nerlich A, Schleicher E (1991) Immunohistochemical localization of extracellular matrix components in human diabetic glomerular lesions. Am J Pathol 139:889-899

12. Nerlich A, Zietz C, Schleicher E (1991) Distribution of basement membrane-associated heparan sulfate proteoglycan in idiopathic and AIDS-associated Kaposi's Sarcoma. Pathol Res Pract 187:444-450

13. Ogbuihi S, Müller Z, Zink P (1988) Zur quantitativen polarisationsmikroskopischen Darstellung von Kollagen Typ I und Typ III an histologischen Paraffinschnitten. Z Rechtsmed 100: 101-111

14. Piérard GE (1989) Sirius Red polarization method is useful to visualize the organization of connective tissues but not the molecular composition of their fibrous polymers. Matrix 9:68-71

15. Stenman S, Vaheri A (1978) Distribution of a new major connective tissue protein, fibronectin, in normal human tissues. J Exp Med 147:1054-1064

16. Timpl R, Wick G, Gay S (1977) Antibodies to distinct types of collagens and procollagens and their application in immunohistology. J Immunol Methods 18:165-182

17. Unsworth DJ, Scott DL, Walton KW, Walker-Smith JA, Holbrow EJ (1984) Failure of R1 type anti-reticulin antibody to react with fibronectin, collagen type $\mathrm{III}$ or the non-collagenous component (NCRC) Clin Exp Immunol 57:609-613 